\title{
Effective natural handicap criteria application for productive and sustainable agricultural land-use management in Lithuania
}

\author{
Gintaras Jarasiunas ${ }^{1}$, Eduardo Corbelle-Rico ${ }^{2}$ and Radoslava Kanianska ${ }^{3}$ \\ ${ }^{1}$ Lithuanian Research Centre for Agriculture and Forestry, Instituto Av. 1, Akademija LT-58344 Kedainiai Distr., Lithuania \\ ${ }^{2}$ Land laboratory, Department of Agricultural and Forest Engineering, Universidade de Santiago de Compostela \\ Higher Polytechnic School of Engineering, Benigno Ledo s/n, 27002 Lugo, Spain \\ ${ }^{3}$ Faculty of Natural Sciences, Matej Bel University Banská Bystrica, Tajovského 40, 97401 Banská Bystrica, Slovakia \\ e-mail: eduardo.corbelle@usc.es
}

\begin{abstract}
Since 1975, European policy has provided some kind of support to areas with specific handicaps for agricultural production, in an attempt to maintain farming activities and population levels in them. The definition of clear criteria for the selection of the so called "Less Favoured Areas" (LFAs) is challenging because of the variability of regions within Europe and the variability of farm characteristics within each region. Actual selection remains very much a deductive approach and empirical evidence is scarce. This study investigates the relationship between the criteria of specific natural handicaps used for the delineation of intermediate LFAs (2014-2020) in Lithuania and generic farming condition and status. Results confirm the negative effects of selected natural handicaps on farm economic status and productive land use but raise some concerns regarding the idoneity of some of them, opening a way for their improvement.
\end{abstract}

Key words: Less Favoured Areas, natural resources, agroecological zones, climatic factors, farm accounting, land evaluation

\section{Introduction}

The idea that not all regions are equally suited for agricultural production as a consequence of specific bio-physical and agro-environmental limitations (e.g. soil quality, climate, terrain), farm structural challenges (e.g. average holding size, average parcel size) or socio-economic characteristics (e.g. farmers' education and age, proximity to main consumption centres) is at the heart of the decline of agricultural activities in many parts of the world and, particularly, in Europe (e.g. Baldock et al. 1996, Strijker 2005, Brouwer et al. 2008). The interest of the European Union (EU) in this issue dates back to the European Council Directive 75/268/EEC on mountain and hill farming in certain Less Favoured Areas (LFAs), an early expression of concerns to ensure the continuation of farming, maintain a minimum population level, and preserve the countryside in these areas. Over time, the objectives of the LFAs measure have evolved from the relative emphasis on prevention of rural depopulation to a more specific interest on continued agricultural land use and sustainability of farming systems, which should contribute to maintain a viable rural community and the countryside as it exists today, as stated by EC Council Regulation 1257/1999 (EC 1999).

The broad definition of LFAs provided by EU directives and regulations has not changed too much since 1975, when two main classes of LFAs where established: mountain areas, affected by difficult climatic conditions (owing to high elevation), steep slopes, or a combination of both; and other less-favoured areas, affected by low productivity or population decline. Nevertheless, small variations took place along time: EC Council Regulation 1257/1999 included a third category of "areas affected by specific handicaps" (limited to a maximum of $10 \%$ or the area of each Member State); Council Regulation 1698/2005 (EC 2005) changed the definition of LFAs other than mountain areas to make it dependent on soil productivity and climate; EC Regulation 1305/2013 went a step further and introduced a set of more explicit indicators in its Annex III.

LFAs are usually associated to low-intensity farming systems and cultural landscapes of high natural value like traditional open landscapes and semi-natural grasslands (European Environment Agency 2004, Cooper et al. 2006). Because of their internal characteristics, but also as a consequence of external drivers, these areas are often pushed towards agricultural marginalization and eventual abandonment of agricultural land use. In fact, farmland abandonment has been common in peripheral and mountainous areas within the $\mathrm{EU}$ in the recent past (e.g. MacDonald et al. 2000). Lasanta et al. (2016) identify at least two main periods of high abandonment rates: the decades of 1950 and 1960, associated to widespread rural exodus and large-scale motorization and mechanization of agricultural practices, and the decade of 1990, associated to CAP reforms and the fall of socialist regimes in Central and Eastern Europe. Abandonment of agricultural activities and the subsequent regrowth of natural 
vegetation imply considerable environmental, and socio-economic impacts that are well described in scientific literature (e.g. Höchtl et al. 2005, García-Ruiz and Lana-Renault 2011, Lasanta et al. 2015). As a consequence, the rural development policy of the EU contemplates payment for areas with specific natural handicaps as the most important measure to prevent farmland abandonment, followed by financial support for land consolidation, afforestation, or early retirement.

Owing to the heterogeneous nature and internal diversity of LFAs, efforts to map them at European level remain a considerable challenge (Eliasson et al. 2010). Not only there are many different reasons why different areas may be considered as "less favoured" (i.e. different biophysical, economic, geographic or socio-economic limitants), but these areas themselves may also be quite diverse internally, in terms of the kind of farms and households that each one contains. The existence of within and between-areas diversity has been highlighted as one of the main limitants to the design efficient indicators and effective policies at EU level (Ruben and Pender 2004, van Keulen 2006). It is for these reasons that the favoured approach has been to allow each Member State to select which areas should be considered as LFAs. This, in turn, might raise additional concerns as some of the designated LFAs may be "less favoured" when compared with other areas within the same State but not necessarily so from a European perspective.

Even apparently subtle changes in the definitions used at the highest level may require changes in the indicators selected for identification of LFAs at national level. For example, Council Regulation 1698/2005 identifies soil productivity and climate as the main characteristics to be monitored for Intermediate LFAs, thus dropping the expression "low agricultural productivity" previously used in EC Council Regulation 1257/1999 (EC 1999). While agricultural productivity depends to a large extent on soil and climate characteristics, it is also affected by technological and social aspects, so the change in the way that the conditions are expressed in the Regulations could result in areas formerly eligible for payments to lose their status and the other way round (Eliasson et al. 2010, van Orshoven et al. 2013).

In Lithuania, the application of the criteria proposed by the EC Regulation of 2005 (following the indicators prescribed by the Order of the Minister of Agriculture of the Republic of Lithuania "Regarding less favoured areas", No. 3D-72, 27 February 2004) resulted in 19 complete municipalities (Local Administrative Units (LAU) level 1, for further details about administrative units in Europe see: http://ec.europa.eu/eurostat/web/nuts/local-administrative-units) and 51 rural wards (LAU 2) being classified as LFAs between the years 2007-2013 (Fig. 1), which account for $42.7 \%$ of the total agricultural area of the country.

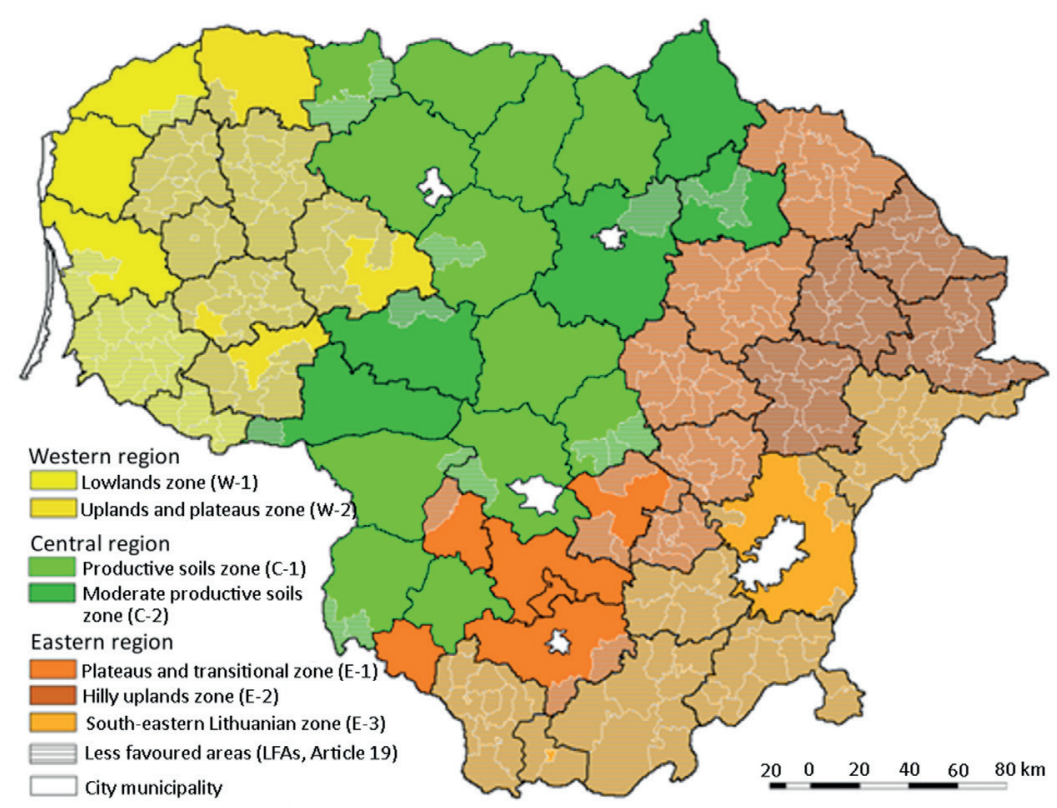

Fig. 1. Agro-ecological regions and zones of Lithuania 
Five of the eight possible biophysical criteria for the delimitation of areas facing natural constraints included in Annex III of EC Regulation 1305/2013 have been selected by Lithuanian authorities for the definition of the nonmountainous areas with natural constraints for the new Rural Development period (Art 33.3 of the proposed regulation on support for rural development by the European Agricultural Fund for Rural Development (EAFRD) 2014-2020, COM(2011) 627 final/3): temperature, soil texture, soil drainage, chemical properties (soil acidity) and terrain-slope; the three non-selected criteria being dryness, excess soil moisture, and shallow rooting depth. The direct support in Lithuania by the EU co-funded "Natural handicap payments for Less Favoured Areas" in 20142020 comprises 257.4 million euros.

Revised delineation of naturally handicapped areas defined by common European biophysical criteria should be supported by proper pedological and meteorological data and methodology for the compilation of nationwide digital maps displaying spatial distribution of specific limiting factors (Pásztor et al. 2013). The criterion system was elaborated by European Commission's Joint Research Centre (van Orshoven et al. 2008). The selection of the aforementioned criteria constitutes a deductive approach that, hopefully, should adequately represent the situation and constraints of the farming sector in Lithuania. Nevertheless, it seems appropriate to question to which extent this deductive approach is backed by empirical evidence. In other words: are farms within designated LFAs in Lithuania effectively affected by profitability limitations, compared to farms in other parts of the country?

In this investigation we aim to explore the relationship between natural constraints (biophysical handicaps) and land and farm characteristics in Lithuania, and analyze in this way the actual effectiveness of the criteria selected by the Lithuanian regulations to identify LFAs in the country. This is accomplished by looking at correlations between variables representative of handicaps as defined in the LFAs indicator criteria and variables representative of basic agricultural land characteristics, farm structure and farm output.

\section{Materials and methods}

\section{Specific natural handicaps}

Lack of data availability limited our approach to just four out of the five criteria currently in force for the identification of LFAs in Lithuania (Council Regulation 1698/2005). More specifically, Lithuanian agricultural land under specific natural biophysical constraints (i.e. climate, soil and terrain) was analysed with reference to the following four criteria:

Climate: low temperature (thermal-time sum (degree-days) for growing period defined by accumulated daily average temperature $>5{ }^{\circ} \mathrm{C}$, threshold is $\leq 1500$ degree-days). In order to take account of between year variability of meteorological conditions, a probabilistic approach is required. It was proposed (van Orshoven et al. 2013) to use the $80 \%$ / 20\% probability exeedance / non exceedance approach, i.e. if in 7 or more years out of 30, the threshold value for severe low temperature condition is not reached, the land was classified as being under severe low temperature limitation. Observations data of Lithuanian meteorological stations $(n=17)$ are 42 -year time-series (1971-2013).

Soil: unfavourable soil texture (topsoil texture class of sand, loamy sand (silt $\%+[2 x$ clay $\%] \leq 30 \%$ ), or heavy clay $(\geq 60 \%$ clay), or organic soil (organic matter $\geq 30 \%$ ) of at least $40 \mathrm{~cm}$ ). Soil particle-size distribution used in current Lithuanian soil database was defined by the amount of separate soil fractions by FAO (2006): sand (2000-63 $\mu \mathrm{m})$, silt $(63-2 \mu \mathrm{m})$ and clay $(<2 \mu \mathrm{m})$. Content of soil organic matter (SOM) was determined by the Walkley-Black procedure.

Soil: poor soil drainage (gleyic colour pattern within $40 \mathrm{~cm}$ from the surface). The World Reference Base for Soil Resources (IUSS Working Group WRB 2006) does use the concept of soil moisture regimes per se, but defines several soil properties directly related to poor drainage, namely gleyic and stagnic features based on soil colour variations. Dominance of reductimorphic features is identified in the soil pit/profile wall by "Gleyic colour pattern" according to WRB (2006). These features are used to define Reference Groups (Gleysols and Stagnosols). Other reference groups are associated with poor internal drainage: the Planosols, Solonetz and Vertisols. According to FAO-ISSSISRIC (Soil Survey Division Staff 1993) standard - poorly or very poorly drained soils determined in Lithuania are:

- Gleysols (lith. šlynžemiai);

- Hyperstagnic Albeluvisols (lith. sekliai stagniniai balkšvažemiai);

- Epihypergleyic Podzols (lith. sekliai glèjiniai jauražemiai);

- Mollic Planosols (lith. puveningieji palvažemiai);

- Umbric Planosols (lith. durpiškieji palvažemiai);

- Pachiterric Histosols (lith. žemapelkès durpžemiai); 
- Endohypergleyic Fluvisols (lith. glèjiniai salpžemiai);

- Umbric Fluvisols (lith. durpiškieji salpžemiai).

According to description data of soil survey by profile horizons, these above-mentioned soil types refers gleyic patterns within whole soil profile from the surface $(1.2-2.0 \mathrm{~m}$ depth) or stagnic patterns from the soil surface at least to $50 \mathrm{~cm}$ or deeper in soil profile.

Terrain: steep slope ( $\geq 15 \%$ or $7^{\circ}$ slope steepness percent or degree respectively).

\section{Spatial and farm datasets}

We used a number of digital cartographic databases (by relating with Lithuania's coordinate system LKS-94, and presented in a digital form at a scale of 1:10 000) to calculate average values of the four aforementioned criteria at LAU 2 (rural ward) level, which we used as our observation unit, and total sample size is 511 . The original quantitative data was taken from the following databases made available by the Lithuanian State Land Fund under the Ministry of Agriculture:

- Control Land Parcels Database (KŽS_DB10LT);

- Digital elevation model (0.5 m/pixel) (SEŽP_0,5LT);

- Lithuanian Soil Database (Dirv_DB10LT);

- Lithuanian Land Drainage Database (Mel_DB10LT);

- Lithuanian Soil Agrochemical Properties Database (DirvAgroch_DB10LT);

- Lithuanian Climate Database (DirvKlim_SL10LT).

On the other hand, data related to key farm socio-economic characteristics and agricultural land structure data were obtained from the Lithuanian Department of Statistics, National Paying Agency under the Ministry of Agriculture. Standard Output (in $€$ ) per farm was calculated from the latest Lithuanian Agricultural Census (Statistics Lithuania 2010). Annual data on average yield of a field crop (collected only from farmers with $\geq 50$ ha of field crops), livestock density (measured as number of cows per declared forage crops area, LSU/ha) and hay yield of meadows and natural pastures was applied following the concept of "fine tuning" "Fine tuning in areas with significant natural constraints"; Discussion paper; Expert group meeting 4/9/2012; "Fine-tuning in areas facing significant natural and specific constraints $11 / 2013^{\prime \prime}$ ), i.e. fine tuning is based on the effects of biophysical handicaps on the gross margin of arable and dairy farms (van Orshoven et al. 2008) includes these above-mentioned variables that are in the final classification of "Natural handicap payments for Less Favoured Areas" in 2014-2020 in Lithuania.

Also, a proxy for land productivity, measured in "points", was used. Land productivity in Lithuania is determined by the systematic units of soil typological groups, soil texture, condition of soil reclamation, agrochemical properties ( $\mathrm{pH}$ value, content of phosphorus and potassium), soil stoniness, soil cover diversity and agro-climatic conditions. These data are incorporated into a single comparative index according to productivity and expressed in points, which are common measure units representing major soil properties (Mažvila et al. 2011). These and the rest of the aforementioned variables are summarized in Table 1.

\section{Statistical analyses}

Natural (log) transformation procedure of data was applied to standardize variables into the same scale to attain the requirements of the normal distribution regarding the data. Log-transformed data was used for exploring any relationships between variables and linear regression testing. The standardized values of the original variables were used for a bivariate Pearson's correlation $(r)$ and determinant $\left(R^{2}\right)$ coefficients calculation (Clewer and Scarisbrick 2001). A paired Student's ( $t$ ) test analysis was performed to identify statistically significant differences in means of selected parameters (crop yield, livestock density, hay yield) between LFAs (LFAs from Western and Eastern regions, $\mathrm{n}=213$ rural wards) and non-LFAs (predominantly in Central region, $\mathrm{n}=12$ rural wards) areas. Conventional statistical significance levels ( $p$-values) of $\alpha=0.01$ and $\alpha=0.05$ were applied. The quantitative data were analysed using SPSS 11.5 software (SPSS Inc., Chicago IL, Field 2009). 
Table 1. Summary of the variables used in the study

\begin{tabular}{|c|c|c|c|c|}
\hline \multirow[t]{2}{*}{ Variable } & \multirow[t]{2}{*}{ Average } & \multirow[t]{2}{*}{$\pm \mathrm{SD}$} & \multicolumn{2}{|c|}{ Range } \\
\hline & & & Min & Max \\
\hline \multicolumn{5}{|l|}{ Natural constraints } \\
\hline Low temperature, $\%$ & 24.47 & 24.28 & 1.38 & 68.17 \\
\hline Unfavourable soil texture, \% & 38.40 & 13.40 & 18.82 & 57.69 \\
\hline Poor soil drainage, $\%$ & 5.44 & 2.39 & 2.44 & 8.69 \\
\hline Steep slope, \% & 1.20 & 0.90 & 0.34 & 2.80 \\
\hline \multicolumn{5}{|l|}{ Crop yield, $\mathrm{t} \mathrm{ha}^{-1} \mathrm{yr}^{-1}$} \\
\hline Barley & 2.76 & 0.61 & 1.82 & 3.46 \\
\hline Triticale & 2.81 & 1.04 & 1.10 & 3.53 \\
\hline Wheat & 3.42 & 1.05 & 2.05 & 5.17 \\
\hline Livestock density, LSU ha-1 & 0.211 & 0.119 & 0.094 & 0.453 \\
\hline Hay yield, $\mathrm{t} \mathrm{ha}^{-1} \mathrm{yr}^{-1}$ & 2.51 & 0.44 & 1.64 & 3.03 \\
\hline \multicolumn{5}{|l|}{ Land and farm characteristics } \\
\hline Utilized agricultural land area per farm (ha) & 13.7 & 5.3 & 8.2 & 23.0 \\
\hline Arable land area per farm (\%) & 54.1 & 23.3 & 15.2 & 78.3 \\
\hline Number of dairy cows per farm & 4.0 & 1.4 & 1.9 & 5.3 \\
\hline Pastures and meadows area per farm (ha) & 4.9 & 1.1 & 3.5 & 6.8 \\
\hline Land under LFAs 2007-2013 (\%) & 53.3 & 38.9 & 0.0 & 100 \\
\hline Declared area under NHP ${ }^{1}$ 2014-2016 (\%) & 32.01 & 24.69 & 3.94 & 55.68 \\
\hline Abandoned land (ha) & 2.34 & 1.83 & 0.69 & 5.42 \\
\hline Common agricultural production value $\left(€ \mathrm{ha}^{-1}\right)$ & 461.2 & 98.9 & 397.4 & 563.6 \\
\hline Standard Output per farm $(€)$ & 7181 & 3965 & 4077 & 14523 \\
\hline \multicolumn{5}{|l|}{ Basic parameters of soil } \\
\hline Land productivity, point & 39.63 & 4.99 & 35.12 & 47.88 \\
\hline Excessive acidity $(\mathrm{pHKCl} \leq 5.5)$ & 22.9 & 14.4 & 4.4 & 41.7 \\
\hline $\mathrm{P}_{2} \mathrm{O}_{5}\left(\mathrm{mg} \mathrm{kg}^{-1}\right)$ & 116 & 17 & 97 & 145 \\
\hline $\mathrm{K}_{2} \mathrm{O}\left(\mathrm{mg} \mathrm{kg}^{-1}\right)$ & 149 & 11 & 136 & 162 \\
\hline
\end{tabular}

\section{Results and discussion}

The deposits composing the surface of the territory of Lithuania are relatively young (their dominant age, except in South Lithuania, is 5000-20000 years). They are of glacial genesis. Lithuanian soils content and chemical composition have been predetermined by glacigenetic features of the territory's formation (Volungevicius et al. 2016). The most productive soils of Lithuania are situated in the Central region (Table 2). The average land productivity of the region is 46.61 points. The second most productive region is Western region with 37.61 points following by the Eastern region (36.33 points). In the Western region, the main natural constraint to agriculture is low temperature.

Table 2. Land productivity, area and share of area under natural climate, soil and terrain constraints at regional and national level

\begin{tabular}{|c|c|c|c|c|c|c|c|c|c|}
\hline \multirow[t]{3}{*}{ Agricultural regions - zones } & \multicolumn{8}{|c|}{ Natural climate, soil and terrain constraints } & \multirow{3}{*}{$\begin{array}{c}\text { Land productivity } \\
\text { Points }\end{array}$} \\
\hline & \multicolumn{2}{|c|}{ Low temperature } & \multicolumn{2}{|c|}{$\begin{array}{l}\text { Unfavourable soil } \\
\text { texture }\end{array}$} & \multicolumn{2}{|c|}{$\begin{array}{l}\text { Poorly soil } \\
\text { drainage }\end{array}$} & \multicolumn{2}{|c|}{ Steep slope } & \\
\hline & $\%$ & ha & $\%$ & ha & $\%$ & ha & $\%$ & ha & \\
\hline \multicolumn{10}{|l|}{ Western region } \\
\hline Lowlands zone (W-1) & 16.46 & 43698 & 46.13 & 122453 & 4.57 & 12139 & 0.34 & 951 & 38.08 \\
\hline $\begin{array}{l}\text { Uplands and plateaus zone } \\
\text { (W-2) }\end{array}$ & 68.17 & 322087 & 38.07 & 179877 & 6.74 & 31820 & 1.00 & 479 & 37.14 \\
\hline Total & 49.57 & 365785 & 40.97 & 302330 & 5.96 & 43959 & 0.77 & 1430 & 37.61 \\
\hline \multicolumn{10}{|l|}{ Central region } \\
\hline Productive soils zone (C-1) & 1.38 & 13510 & 18.82 & 184245 & 2.52 & 24689 & 0.42 & 4067 & 47.88 \\
\hline $\begin{array}{l}\text { Moderately productive soils } \\
\text { zone (C-2) }\end{array}$ & 22.35 & 110714 & 23.72 & 117497 & 2.44 & 12086 & 0.51 & 2509 & 45.34 \\
\hline Total & 8.43 & 124234 & 20.47 & 301742 & 2.49 & 36775 & 0.45 & 6576 & 46.61 \\
\hline \multicolumn{10}{|l|}{ Eastern region } \\
\hline $\begin{array}{l}\text { Plateaus and transitional zone } \\
\text { (E-1) }\end{array}$ & 9.48 & 61412 & 39.22 & 254042 & 5.80 & 37562 & 1.77 & 11434 & 38.51 \\
\hline Hilly uplands zone (E-2) & 46.60 & 123443 & 45.17 & 119644 & 8.69 & 23024 & 2.80 & 7413 & 35.35 \\
\hline $\begin{array}{l}\text { South-eastern Lithuanian zone } \\
\text { (E-3) }\end{array}$ & 6.85 & 26138 & 57.69 & 220224 & 7.35 & 28054 & 1.58 & 6048 & 35.12 \\
\hline Total & 16.30 & 210993 & 45.89 & 593910 & 6.85 & 88641 & 1.92 & 24895 & 36.33 \\
\hline Lithuania & 19.33 & 701012 & 33.59 & 1197982 & 4.76 & 169374 & 1.03 & 32901 & 40.18 \\
\hline
\end{tabular}


The Eastern region has a combination of three constraints: unfavourable soil texture, poor soil drainage, and steep slope which is reflected in the dominance of LFAs in this region (Fig. 2). From the spatial point of view, low temperature and unfavourable soil texture are dominant limited criteria to generic agricultural activity within the regions.

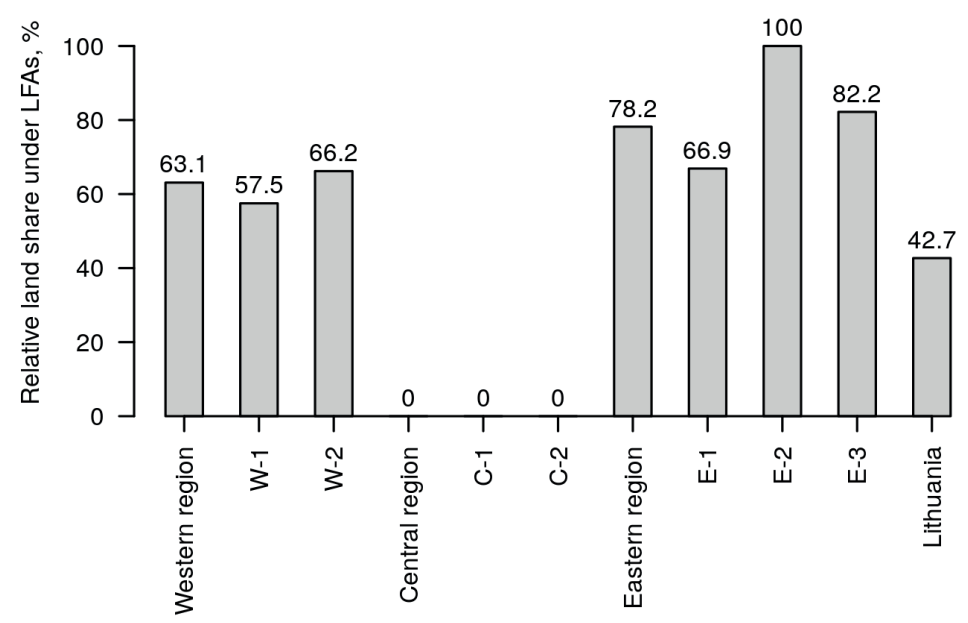

Fig. 2. LFAs in Lithuanian agro-ecological regions and zones

The highest crop yield of triticale and wheat was measured in the most productive Central region without any significant natural handicaps (Table 3). Cambisols prevailing in Central Lithuania are particularly fertile and well drained.This agro-ecological region is superior to other regions in the country. According to the analysis conducted at the Lithuanian Institute of Agrarian Economics, marketable plant growing is profitable only in regions where agricultural land productivity exceeds the mean value of the whole country (Povilaitis et al. 2015). In the Eastern region due to combination of several natural constraints we observed the lowest wheat and triticale yields. Surprisingly, barley reached the highest yield $\left(3.21 \mathrm{t} \mathrm{ha}^{-1} \mathrm{yr}^{-1}\right)$ in the Western region typical in low temperature which could be influenced by other no natural factors, e.g. land management practices or other agronomic interventions induced by farmers.

\begin{tabular}{|c|c|c|c|c|c|}
\hline \multirow{2}{*}{ Agricultural regions - zones } & \multicolumn{3}{|c|}{ Crop yield, $\mathrm{t} \mathrm{ha}^{-1} \mathrm{yr}^{-1}$} & \multirow{2}{*}{$\begin{array}{c}\text { Livestock } \\
\text { density }\end{array}$} & \multirow{2}{*}{$\begin{array}{l}\text { Hay yield, } \\
\mathrm{t} \mathrm{ha}^{-1} \mathrm{yr}^{-1}\end{array}$} \\
\hline & Barley & Triticale & Wheat & & \\
\hline \multicolumn{6}{|l|}{ Western region } \\
\hline Lowlands zone (W-1) & 2.95 & 2.68 & 3.09 & 0.268 & 2.57 \\
\hline Uplands and plateaus zone (W-2) & 3.46 & 2.54 & 3.76 & 0.453 & 2.41 \\
\hline Total & 3.21 & 2.61 & 3.42 & 0.361 & 2.49 \\
\hline \multicolumn{6}{|l|}{ Central region } \\
\hline Productive soils zone $(\mathrm{C}-1)$ & 2.87 & 3.53 & 5.00 & 0.192 & 2.73 \\
\hline Moderately productive soils zone (C-2) & 3.39 & 4.40 & 4.08 & 0.183 & 3.03 \\
\hline Total & 3.13 & 3.97 & 4.54 & 0.188 & 2.88 \\
\hline \multicolumn{6}{|l|}{ Eastern region } \\
\hline Plateaus and transitional zone $(\mathrm{E}-1)$ & 2.73 & 3.20 & 3.76 & 0.158 & 2.38 \\
\hline Hilly uplands zone (E-2) & 2.10 & 2.24 & 2.05 & 0.132 & 1.64 \\
\hline South-eastern Lithuanian zone $(E-3)$ & 1.82 & 1.10 & 2.23 & 0.094 & 2.78 \\
\hline Total & 2.22 & 2.18 & 2.68 & 0.128 & 2.27 \\
\hline Lithuania & 2.85 & 2.92 & 3.55 & 0.226 & 2.55 \\
\hline
\end{tabular}


The highest livestock density was in Western region and zones and it was higher than the average value in Lithunia. The minimum and maximum yield of hay was 1.64 and $3.03 \mathrm{t} \mathrm{ha}^{-1} \mathrm{yr}^{-1}$, respectively. Central region is characterised by the highest hay yield, on average of $2.88 \mathrm{t} \mathrm{ha}^{-1} \mathrm{yr}^{-1}$, i.e. 14 and $21 \%$ more when compared to Western and Eastern regions, respectively.

Table 4. A paired t-test results on differences between LFAs and non-LFAs

\begin{tabular}{|c|c|c|c|c|c|c|c|c|c|}
\hline \multicolumn{6}{|c|}{ Crop yield, $\mathrm{t} \mathrm{ha}^{-1} \mathrm{yr}^{-1}$} & \multicolumn{2}{|c|}{ Livestock density } & \multicolumn{2}{|c|}{ Hay yield, $\mathrm{t} \mathrm{ha}^{-1} \mathrm{yr}^{-1}$} \\
\hline \multicolumn{2}{|c|}{ Barley } & \multicolumn{2}{|c|}{ Triticale } & \multicolumn{2}{|c|}{ Wheat } & \multirow[b]{2}{*}{ tact. } & \multirow[b]{2}{*}{$p$} & \multirow[b]{2}{*}{ tact. } & \multirow[b]{2}{*}{$p$} \\
\hline tact. & $p$ & tact. & $p$ & tact. & $p$ & & & & \\
\hline-1.084 & 0.042 & 3.083 & 0.029 & 8.518 & 0.001 & -2.376 & 0.031 & 1.304 & 0.212 \\
\hline
\end{tabular}

Also t-test confirmed stastical differences in means of selected parameters between LFAs and non-LFAs (Table 4). The results of these tests indicate the existence of significant $(p \leq 0.05)$ differences in verage yield of barley, triticale and wheat between LFAs and non-LFAs. Significant difference was also observed by the livestock density variable, where the quantity of cows was higher $(p=0.031)$ in LFAs compared to the non-LFAs. Hay yield produced by natural pastures and meadows is not significantly different between LFAs and non-LFAs, which may partially explain why the former tend to specialize in cattle husbandry.

Table 5. Correlation $(r)$ and determinant $\left(R^{2}\right)$ coefficients between crop yields, livestock density and variables selected as LFAs indicators

\begin{tabular}{|c|c|c|c|c|c|c|c|c|c|c|c|c|}
\hline \multirow[t]{2}{*}{ Variable } & \multicolumn{3}{|c|}{ Low temperature } & \multicolumn{3}{|c|}{ Unfavourable soil texture } & \multicolumn{3}{|c|}{ Poor soil drainage } & \multicolumn{3}{|c|}{ Steep slope } \\
\hline & $r$ & $p$ & $\mathrm{R}^{2}$ & $r$ & $p$ & $\mathrm{R}^{2}$ & $r$ & $p$ & $\mathrm{R}^{2}$ & $r$ & $p$ & $\mathrm{R}^{2}$ \\
\hline Barley yield, $\mathrm{t} \mathrm{ha}^{-1} \mathrm{yr}^{-1}$ & 0.271 & 0.278 & 0.074 & -0.688 & 0.044 & 0.473 & -0.635 & 0.063 & 0.404 & -0.676 & 0.048 & 0.456 \\
\hline Triticale yield, $\mathrm{t} \mathrm{ha}^{-1} \mathrm{yr}^{-1}$ & -0.011 & 0.491 & 0.000 & -0.868 & 0.001 & 0.753 & -0.721 & 0.034 & 0.510 & -0.446 & 0.158 & 0.199 \\
\hline Wheat yield, $\mathrm{t}$ ha $\mathrm{yr}^{-1}$ & -0.198 & 0.355 & 0.039 & -0.859 & 0.007 & 0.737 & -0.829 & 0.011 & 0.687 & -0.723 & 0.033 & 0.523 \\
\hline Livestock density & 0.572 & 0.090 & 0.327 & -0.331 & 0.234 & 0.110 & -0.232 & 0.309 & 0.054 & -0.513 & 0.119 & 0.263 \\
\hline Hay yield, $\mathrm{t} \mathrm{ha}^{-1} \mathrm{yr}^{-1}$ & -0.509 & 0.122 & 0.259 & -0.323 & 0.240 & 0.105 & -0.733 & 0.030 & 0.537 & -0.817 & 0.012 & 0.667 \\
\hline
\end{tabular}

The analysis of correlation between variables selected as LFAs indicators and average crop yields statistically confirmed that productive agroecosystem functions do not correlate with all the variables defined as indicators (Table 5). Diverse indicators showed significant correlation with various production related variables. For example, soil texture, soil drainage, and terrain-slope showed correlation with all or some of the yield variables. In particular, soil texture appeared to be associated with crop yield, but not with hay yield, while soil drainage and terrainslope showed significant correlation with all but one of these variables. Somewhat surprisingly, growing season weather conditions did not show a significant correlation with any of the analyzed yield variables. On the other hand, none of the indicator variables was correlated with livestock density, suggesting that farms depend on forage import or that forage production is not as sensitive to these variables as other crops are.

Soil texture significantly correlated with cereal but not with hay yield. Soil texture, defined by particle size, control hydrological and geomorphologic processes as soil water holding and cation exchange capacity, nutrient availablitly and thus crop yield (Chaudhari et al. 2008) seems equally important, although it did not appear to be related to barley yield. In addition, Shahandeh et al. (2005) showed significant correlation between soil texture, clay content, and nitrogen mineralization which affected $\mathrm{N}$ budget and corn grain yield. Zipper et al. (2015) defined soil texture as a baseline upon which water table depth and weather interact to determine overall yield. Mainly coarse soil characterised by less clay and more sand is less productive. But water use efficiency and consequently yield can be also significantly reduced by high clay content in soil (Katerji and Mastrorilli 2009).

In the case of hay yield, soil drainage and steep slope play a very important role. Grasslands require a well-drained soil for optimum production. Wet soils create conditions suitable for diseases that may reduce forage yield. Poor soil drainge also reduces the movement of soil oxygen to roots, causes poor soil aeration, and micronutrient toxicity (Undersander et al. 2011). Sloping fields have low spots where water stands, and thus create better conditions for hay yield. Soils under hilly topography status are not suitable for successful growing of crops by reason 
of steep slopes relating to intensive water erosion, which cause potential reduction of crop yield and land degradation processes (Jarasiunas et al. 2017). Even negative influence of steep slopes on hay yield was observed, on steeper than $7^{\circ}(12 \%)$ slopes, grass-grain crop rotation is recommended (Jankauskas et al. 2004, Kinderienè et al. 2013) because this measure proved effective in preventing water and tillage erosion and increasing soil fertility and land productivity on the hilly terrain (Jarašiūnas and Kinderienè 2016). However, Lithuania as lowland country offers steep slope conditions only in some regions.

Table 6. Correlation ( $r$ ) and determinant (R2) coefficients between the natural handicap criteria and basic land and farm characteristics

\begin{tabular}{|c|c|c|c|c|c|c|c|c|c|c|c|c|}
\hline \multirow[t]{2}{*}{ Variable } & \multicolumn{3}{|c|}{ Low temperature } & \multicolumn{3}{|c|}{$\begin{array}{c}\text { Unfavourable soil } \\
\text { texture }\end{array}$} & \multicolumn{3}{|c|}{ Poor soil drainage } & \multicolumn{3}{|c|}{ Steep slope } \\
\hline & $r$ & $p$ & R2 & r & $p$ & $\mathrm{R} 2$ & $r$ & $p$ & R2 & $r$ & $p$ & R2 \\
\hline $\begin{array}{l}\text { Utilized agricultural land area } \\
\text { per farm (ha) }\end{array}$ & -0.143 & 0.380 & 0.020 & -0.786 & 0.018 & 0.618 & -0.893 & 0.003 & 0.797 & -0.713 & 0.036 & 0.508 \\
\hline Arable land area per farm (\%) & -0.321 & 0.241 & 0.103 & -0.636 & 0.063 & 0.405 & -0.857 & 0.007 & 0.734 & -0.929 & 0.001 & 0.863 \\
\hline Number of dairy cows per farm & -0.071 & 0.440 & 0.005 & -0.705 & 0.039 & 0.497 & -0.786 & 0.018 & 0.618 & -0.893 & 0.003 & 0.797 \\
\hline $\begin{array}{l}\text { Pastures and meadows area per } \\
\text { farm (ha) }\end{array}$ & 0.821 & 0.012 & 0.674 & 0.321 & 0.241 & 0.103 & 0.357 & 0.216 & 0.127 & 0.179 & 0.351 & 0.032 \\
\hline Land under LFAs 2007-2013 (\%) & 0.386 & 0.195 & 0.149 & 0.876 & 0.005 & 0.767 & 0.969 & 0.001 & 0.939 & 0.786 & 0.018 & 0.618 \\
\hline $\begin{array}{l}\text { Declared area under NHP1 } \\
\text { 2014-2016 (\%) }\end{array}$ & 0.679 & 0.047 & 0.461 & 0.609 & 0.073 & 0.371 & 0.911 & 0.002 & 0.821 & 0.808 & 0.014 & 0.653 \\
\hline Abandoned land (ha) & 0.179 & 0.351 & 0.032 & 0.821 & 0.012 & 0.674 & 0.857 & 0.007 & 0.734 & 0.750 & 0.026 & 0.563 \\
\hline $\begin{array}{l}\text { Common agricultural production } \\
\text { value }\left(€ \mathrm{ha}^{-1}\right)\end{array}$ & -0.357 & 0.230 & 0.127 & -0.718 & 0.034 & 0.516 & -0.853 & 0.007 & 0.728 & -0.811 & 0.013 & 0.658 \\
\hline Standard Output per farm $(€)$ & -0.198 & 0.335 & 0.039 & -0.865 & 0.006 & 0.748 & -0.847 & 0.008 & 0.717 & -0.719 & 0.034 & 0.517 \\
\hline
\end{tabular}

${ }^{1} \mathrm{NHP}=$ Natural Handicap Payments 2014-2020 (former LFAs, Article 19; EC 2009)

Correlation between variables used as indicators of LFAs (natural handicap variables) and basic land and farm characteristics showed significant results in many instances (Table 6). In particular, poor soil drainage and steep slope showed correlation with most of the variables analyzed, particularly a negative correlation with farm size (utilized agricultural area, arable area, number of animals), production value and standard output, but a positive correlation with the amount of abandoned land. Soils with natural handicaps as poor soil drainage, steep slope or unfavourable soil texture are not predominantly used as agricultural or arable land or for dairy production. According to Ribokas (2013) and Gauděšius (2016) income from agricultural activities is lower in unproductive territories than in fertile ones, and this usually makes agricultural activities less profitable in some regions of Lithuania. The empirical survey conducted by Jarašiūnas and Kinderienè (2015) noticed that hazards, even such as socioeconomic determinants, depend on natural land-soil productivity. In such situations, other sources of income have become an important component of total farm income, with LFA subsidies having positive impacts on the local regional GDP and per capita income (Giannakis et al. 2014). Nevertheless, Baráth et al. (2018) have shown how technical efficiency of farms located in LFAs is not necessarily very different from that of farms outside LFAs. While this may be the consequence of adaptation strategies at farm level to overcome bio-physical constraints, in some cases there may be also room for improvement in the criteria for LFA identification.

We found high significant positive correlation between poor soil drainage and land under LFAs, NHP or land abandonment. Significant positive correlation was also observed between steep slope and land under LFAs, NHP or abandonment. Strong positive correlation was found between unfavourable soil texture and land under LFAs or abandonment. Despite the fact that areas with unfavourable soil texture are used as arable land, their production value and output are low. Only low temperature as the natural handicap variable did not correlate with the area of land under LFAs or abandonment but appeared to be associated with NHP areas delineation. On the other hand, low temperature during the growing season showed no correlation with most of farm characteristics.

Table 7. Correlation ( $r$ ) and determinant (R2) coefficients between the natural handicap criteria and basic parameters of soil

\begin{tabular}{|c|c|c|c|c|c|c|c|c|c|c|c|c|}
\hline \multirow[t]{2}{*}{ Soil parameter } & \multicolumn{3}{|c|}{ Low temperature } & \multicolumn{3}{|c|}{ Unfavourable soil texture } & \multicolumn{3}{|c|}{ Poor soil drainage } & \multicolumn{3}{|c|}{ Steep slope } \\
\hline & $r$ & $p$ & $\mathrm{R} 2$ & $r$ & $p$ & $\mathrm{R} 2$ & $r$ & $p$ & $\mathrm{R} 2$ & $r$ & $p$ & $\mathrm{R} 2$ \\
\hline Land productivity & -0.553 & 0.099 & 0.306 & -0.965 & 0.001 & 0.932 & -0.964 & 0.001 & 0.930 & -0.689 & 0.043 & 0.475 \\
\hline $\begin{array}{l}\text { Excessive acidity } \\
(\mathrm{pHKCl} \leq 5.5)\end{array}$ & 0.564 & 0.093 & 0.318 & 0.908 & 0.002 & 0.825 & 0.763 & 0.023 & 0.583 & 0.300 & 0.256 & 0.090 \\
\hline $\mathrm{P}_{2} \mathrm{O}_{5}\left(\mathrm{mg} \mathrm{kg}^{-1}\right)$ & -0.943 & 0.001 & 0.888 & -0.309 & 0.250 & 0.096 & -0.298 & 0.258 & 0.089 & -0.065 & 0.445 & 0.004 \\
\hline $\mathrm{K}_{2} \mathrm{O}\left(\mathrm{mg} \mathrm{kg}^{-1}\right)$ & -0.122 & 0.397 & 0.015 & -0.393 & 0.191 & 0.154 & 0.019 & 0.484 & 0.000 & 0.363 & 0.212 & 0.132 \\
\hline
\end{tabular}


Poor soil drainage and unfavourable soil texture as the natural handicaps are the main drivers of low land productivity including some effect of steep slope (Table 7). Excessive acidity appears to be positively correlated with unfavourable soil texture and poor soil drainage. Low temperature negativelly correlated with plant-available $\mathrm{P}_{2} \mathrm{O}_{5}$. The negative effect of unfavourable soil texture and poor soil drainage is then multiplied. Excessive acidity is usually characterized by poor fertility and is one of the major constraints for crop production. Pagani and Mallarino (2012) reported that soil acidity influences many chemical and biological reactions that control plant nutrient availability and the toxicity of some elements, and is a serious limitations for crop production in many regions of the world. Excessive acidity can be related to $\mathrm{Al}^{3+}$ toxicity and low base saturation (Nora and Amado 2013). Root growth of crop plants is also reduced in acid soils (Skuodiene et al. 2017). But if the chemical constraints like excessive acidity are eliminated by liming and using adequate amounts of fertilizers, the yields can be increased.

\section{Conclusions}

Results confirm, to a large extent, that the criteria for LFAs delineation in Lithuania were properly selected, and allowed to shed some light into the issue of their relative importance. The analysis of the correlation of soil texture, soil drainage and terrain-slope with average crop and hay yields, as well as with basic farm characteristics, allowed to confirm that these are relevant variables that establish clear differences between different rural wards (LAU 2) in Lithuania. The relevance of average temperatures during the growing season, on the other hand, seemed less clear, at least for the analysed variables and at the selected territorial administrative scale.

Being aware of the difficulties involved in the selection of good indicator variables for the identification of LFAs, we believe that our analysis should be complemented and augmented in the future with the inclusion of other variables and, hopefully, modelling at other scales to gather a better understanding of the influence of natural limitants to agricultural production, not only in the Baltic sea region but also at EU scale. A broader and more ambitious modelling exercise could involve the use of Farm Accountancy Data Network (FADN) data and biophysical indicators at LAU 2 (or, at least, NUTS 3) level for a sample of administrative units across Europe. In the meantime, we hope these results can be used for fine tuning of LFA delineation in agro-ecological regions and zones in Lithuania.

\section{References}

Baldock, D., Beaufoy, G., Brouwer, F. \& Godeschalk, F. 1996. Farming at the margins: abandonment or redeployment of agricultural land in Europe. The Hague: Agricultural economics research institute. 202 p.

Baráth, L., Fertő, I. \& Bojnec, Š. 2018. Are farms in less favoured areas less efficient? Agricultural Economics 49: 3-12. https:// doi.org/10.1111/agec.12391

Brouwer, F.M., van Rheenen, T., Dhillion, S. \& Elgersma, A.M. 2008. Sustainable land management: strategies to cope with the marginalization of agriculture. Cheltenham, UK: Edward Elgar Publishing. 252 p.

Chaudhari, S.K., Singh, R. \& Kundu, D.K. 2008. Rapid textural analysis for saline and alkaline soils with different physical and chemical properties. Soil Science Society of America Journal 72: 431-441. https://doi.org/10.2136/sssaj2006.0117N

Clewer, A.G. \& Scarisbrick, D.H. 2001. Practical statistics and experimental design for plant and crop science. New York, USA: John Wiley \& Sons. 346 p.

Cooper, T., Baldock, D., Rayment, M., Kuhmonen, T., Terluin, I., Swales, V., Poux, X., Zakeossian, D. \& Farmer, M. 2006. An evaluation of the less favoured area measure in the 25 member states of the European Union. London: Institute for European Environmental Policy. 262 p.

EC 1999. Council Regulation (EC) No 1257/1999 of 17 May 1999 on support for rural development from the European Agricultural Guidance and Guarantee Fund (EAGGF) and amending and repealing certain Regulations. The Official Journal of the European Union L160: 80-102.

EC 2009. Towards a better targeting of the aid to farmers in areas with natural handicaps. 21.04.2009. COM (2009) 161 final.

EC 2003. Council Regulation (EC). No 1059/2003 on the establishment of a common classification of territorial units for statistics (NUTS). The Official Journal of the European Union L 154, 21.6.2003.

EC 2005. Council Regulation (EC). No 1698/2005 No 1698/2005 of 20 September 2005. The Official Journal of the European Union L 277/1, 21.10.2005.

EC 2013. Council Regulation (EC). No 1305/2013 on support for rural development by the European Agricultural Fund for Rural Development (EAFRD) and repealing Council Regulation (EC) No 1698/2005.

Eliasson, Å., Jones, R.J.A., Nachtergaele, F., Rossiter, D.G., Terres, J.-M., van Orshoven, J., van Velthuizen, H., Böttcher, K., Haastrup, P. \& Le Bas, C. 2010. Common criteria for the redefinition of Intermediate Less Favoured Areas in the European Union. Environmental Science \& Policy 13: 766-777. https://doi.org/10.1016/j.envsci.2010.08.003

European Environment Agency 2004. High nature value farmland. Characteristics, trends and policy challenges. Report 1/2004. Office for Official Publications of the European Communities, Luxembourg. https://www.eea.europa.eu/publications/report_2004_1 
FAO 2006. Guidelines for Soil Description (4th ed). Rome, Italy: FAO. 97 p.

FAO 1998. World Reference Base for Soil Resources. World Soil Resources Report no. 84. Food and Agriculture Organization of the United Nations, Rome, Italy. 58 p.

FAO 2006. World Reference Base for Soil Resources (2nd ed.). World Soil Resources Report no. 103. Food and Agriculture Organization of the United Nations, Rome, Italy. 128 p.

Field, A. 2009. Discovering Statistics Using SPSS. London: SAGE publications. 821 p.

García-Ruiz, J.M. \& Lana-Renault, N. 2011. Hydrological and erosive consequences of farmland abandonment in Europe, with special reference to the Mediterranean region - a review. Agriculture, Ecosystems \& Environment 140: 317-338. https://doi. org/10.1016/j.agee.2011.01.003

Gauděšius, R. 2016. Drawing up maps of infertile soil plots using geographic information systems. Geodesy and Cartography 42 : 140-145. https://doi.org/10.3846/20296991.2016.1268437

Giannakis, E., Efstratoglou, S. \& Psaltopoulos, D. 2014. Modelling the impacts of alternative CAP scenarios through a system dynamics approach. Agricultural Economics Review 15: 48-67.

Höchtl, F., Lehringer, S. \& Konold, W. 2005. "Wilderness": what it means when it becomes a reality - a case study from the southwestern Alps. Landscape and Urban Planning 70: 85-95. https://doi.org/10.1016/j.landurbplan.2003.10.006

Jankauskas, B., Jankauskiene, G. \& Fullen, M.A. 2004. Erosion-preventive crop rotations and water erosion rates on undulating slopes in Lithuania. Canadian Journal of Soil Science 84: 177-186. https://doi.org/10.4141/S03-029

Jarasiunas, G., Kinderiene, I. \& Bašić, F. 2017. Delineation Lithuanian agricultural land for agro-ecological suitability for farming using soil and terrain criteria. Ekológia (Bratislava) 36: 88-100. https://doi.org/10.1515/eko-2017-0008

Jarašiūnas, G. \& Kinderienė, I. 2015. Evaluation of generic farming conditions in Eastern Lithuania. Žemès ūkio mokslai 22: 65-73.

Jarašiūnas, G. \& Kinderienè, I. 2016. Impact of agro-environmental systems on soil erosion processes and soil properties on hilly landscape in Western Lithuania. Journal of Environmental Engineering and Landscape Management 24: 60-69. https://doi.org/ 10.3846/16486897.2015.1054289

Katerji, N. \& Mastrorilli, M. 2009. The effect of soil texture on the water use efficiency of irrigated crops: results of a multi-year experiment carried out in the Mediterranean region. European Journal of Agronomy 30: 95-100. https://doi.org/10.1016/j. eja.2008.07.009

Kinderienė, I., Jarašiūnas, G. \& Karčauskienė, D. 2013. Augalų maisto medžiagų (N, P, K) nuo kalvų šlaitų praradimas su dirvožemiu ir vandeniu. Žemès ūkio mokslai 20: 10-19. (in Lithuanian).

Lasanta, T., Arnįez, J., Pascual, N., Ruiz-Flańo, P., Errea, M.P. \& Lana-Renault, N. 2016. Space-time process and drivers of land abandonment in Europe. Catena 149: 810-823. https://doi.org/10.1016/j.catena.2016.02.024

Lasanta, T., Nadal-Romero, E. \& Arnįez, J. 2015. Managing abandoned farmland to control the impact of re-vegetation on the environment. The state of art in Europe. Environmental Science \& Policy 52: 99-109. https://doi.org/10.1016/j.envsci.2015.05.012

MacDonald, D., Crabtree, J.R., Wiesinger, G., Dax, T., Stamou, N., Fleury, P., Gutierrez Lazpita, J. \& Gibon, A. 2000. Agricultural abandonment in mountain areas of Europe: Environmental consequences and policy response. Journal of Environmental Management 59: 47-69. https://doi.org/10.1006/jema.1999.0335

Mažvila, J., Staugaitis, G., Vaišvila, Z., Aleknavičius, P., Juozokas, A., Mockevičius, R. \& Lukšienė, L. 2011. Lietuvos žemių našumas. Akademija: Lietuvos agrarinių ir miškų mokslų centras. 280 p. (in Polish).

Nora, D.D. \& Amado, T.J.C. 2013. Improvement in chemical attributes of oxisol subsoil and crop yields under no-till. Agronomy Journal 105: 1393-1403. https://doi.org/10.2134/agronj2013.0031

Pagani, A. \& Mallarino, A.P. 2012. Soil pH and crop grain yield as affected by the source and rate of lime. Soil Science Society of America Journal 76: 1877-1886. https://doi.org/10.2136/sssaj2012.0119

Pịsztor, L., Szabó, J., Bakacsi, Z. \& Laborczi, A. 2013. Elaboration and applications of spatial soil information systems and digital soil mapping at Research Institute for Soil Science and Agricultural Chemistry of the Hungarian Academy of Sciences. Geocarto International 28: 13-27. https://doi.org/10.1080/10106049.2012.685895

Povilaitis, A., Lamsodis, R., Bastienė, N., Rudzianskaitė, A., Misevičienė, S., Miseckaitè, O., Gužys, S., Baigys, G., Grybauskienė, V. \& Balevičius, G. 2015. Agricultural drainage in Lithuania: a review of practices and environmental effects. Acta Agriculturae Scandinavica, Section B - Soil \& Plant Science, 65 (sup1): 14-29.

Ribokas, G. 2013. Kai kurie mažiau palankių ūkininkauti teritorijų žemės ūkio intensyvumo aspektai. Geografijos metraštis 46: 62-71.

Ruben, R. \& Pender, J. 2004. Rural diversity and heterogeneity in less-favoured areas: the quest for policy targeting. Food Policy 29: 303-320. https://doi.org/10.1016/j.foodpol.2004.07.004

Shahandeh, H., Wright, A.L., Hons, F.M. \& Lasano, R.J. 2005. Spatial and temporal variation of soil nitrogen parameters related to soils texture and corn yield. Journal of Agronomy 97: 772-782. https://doi.org/10.2134/agronj2004.0287

Skuodienè, R., Tomchuk, D. \& Aleinikovienė, J. 2017. Plant root morphology and soil biological indicators under primary development of various swards. Acta Agriculturae Scandinavica, Section B - Soil \& Plant Science 67: 435-443.

Soil Survey Division Staff 1993. Soil Survey Manual. USDA Handbook No. 18. Washington DC, USA: US Government Printing Office. $437 \mathrm{p}$.

Statistics Lithuania 2010. Results of the Agricultural Census of the Republic of Lithuania 2010 by ward. Lithuania, Vilnius: Lithuanian Department of Statistics (Statistics Lithuania). 168 p. 
Strijker, D. 2005. Marginal lands in Europe - causes of decline. Basic and Applied Ecology 6: 99-106. https://doi.org/10.1016/j. baae.2005.01.001

Undersander, D., Cosgrove, D., Cullen, E., Crain, G., Rice, M.E., Renz, M., Sheaffer, C., Shewmaker, G. \& Sulc, M. 2011. Alfalfa Management Guide. Madison, USA: American Society of Agronomy, Inc., Crop Science Society of America, Inc., Soils Science Society of America, Inc. 68 p. https://www.agronomy.org/files/publications/alfalfa-management-guide.pdf

van Keulen, H. 2006. Heterogeneity and diversity in less-favoured areas. Agricultural Systems 88: 1-7. https://doi.org/10.1016/j. agsy.2005.06.001

van Orshoven, J., Terres J.-M. \& Tóth, T. 2013. Updated common bio-physical criteria to define natural constraints for agriculture in Europe. Definition and scientific justification for the common criteria. Luxembourg: Publications Office of the European Union, 201. 66 p. http://agrienv.jrc.ec.europa.eu/publications/Updated-ANC-biophysical.pdf

Volungevicius, J., Jukna, L., Veteikis. D., Vaisvalavicius. R., Amaleviciute, K., Slepetiene, A., Skorupskas, R. \& Jankauskaite, R. 2016. The problem of soil interpretation according to the WRB 2014 classification system in the context of anthropogenic transformations. Acta Agriculturae Scandinavica, Section B - Soil \& Plant Science 66: 452-460.

Zipper, S.C., Soylu, M.E., Booth, E.G. \& Loheide, S.P. 2015. Untangling the effects of shallow groundwater and soil texture as drivers of subfield-scale yield variability. Water Resources Research 51: 6338-6358. https://doi.org/10.1002/2015WR017522 